УДК 553.98; https://doi.org/10.37878/2708-0080/2021-4.02

\title{
НЕФТЕГАЗОВАЯ ГЕОЛОГОРАЗВЕДКА И ЮНИОРНЫЕ КОМПАНИИ: ПРИМЕР ПОИСКОВОГО ПРОЕКТА В ПОЯСЕ НАДВИГОВ ПРИПОЛЯРНОГО УРАЛА
}

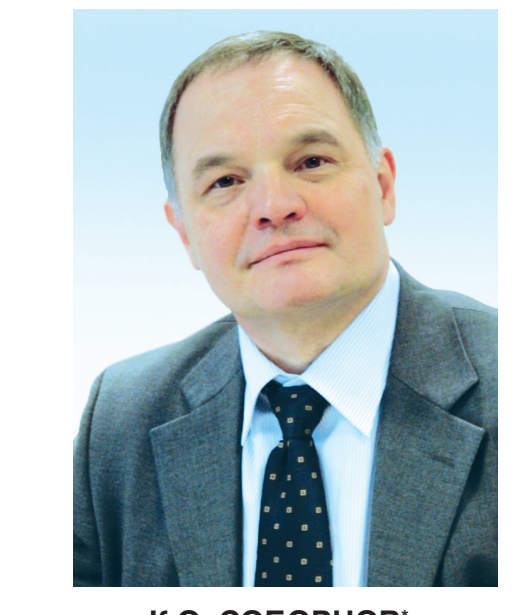

\author{
К.О. СОБОРНОВ \\ доктор геол.-мин. наук, \\ основатель ООО «Северо-Уральская \\ нестегазовая компания», \\ https://orcid.org/0000-0002-9073-8492
}

ООО «СУНГК»,

Российская Федерация, 142784, г. Москва, Киевское ш. 1, БП «Румянцево»

Анализ тенденций нефтегазовой отрасли в мире дает основание прогнозировать рост значимости геологоразведки. До перехода на возобновляемые источники топлива она призвана дать новые качественные запасы нефти и газа, которые обеспечат потребности в энергоносителях. Они должны прийти на смену истощенным месторождениям, разработка которых имеет высокий углеводородный след. Мировой опыт показывает, что в рыночной среде с задачей поисков новых месторождений удачно справляются юниорные компании. Их отличает мобильность и широкое применение новых технологий и знаний. Наилучшие результаты их деятельности отмечаются в районах сложного строения, где инновации позволяют выявлять новые зоны нефтегазонакопления. Современные данные показывают, что большим потенциалом новых открытий обладает Предуралье на территории России и Казахстана. Опыт работы Северо-Уральской нефтегазовой компании дает пример нового проекта, который позволил выявить перспективную структуру, способную содержать крупные запасы нефрти и газа.

КЛЮчЕВЫЕ СЛОВА: геологоразведка, ресурсная база, нефть, газ, качественные запасы, юниорные компании, инновационные технологии, Предуралье, гряда Чернышева, пояс надвигов, соляные диапиры.

* Адрес для переписки. E-mail: ksobornov@yandex.ru 


\section{МҰНАЙ-ГАЗ ГЕОЛОГИЯЛЫҚ БАРЛАУ ЖӘНЕ ЮНИОРЛЫҚ КОМПАНИЯЛАР: ПОЛЯРЛЫҚ ОРАЛДЫҢ АЛДЫНДАҒЫ ЖЫЛЖЫТУ БЕЛДЕУДЕГІ ІЗДЕУ ЖОБАСЫНЫҢ МЫСАЛЫ}

к.О. СОБОРнОВ компаниясы", https://orcid.org/0000-0002-9073-8492

ООО «СУНГК»,

Ресей Федерациясы, 142784, Мәскеу қ., Киев ш. 1, БП «Румянцево»

Әлемдегі мұнай-газ саласының үрдістерін талдау геологиялық барлау маңыздылығының өсуінің болжауға негіз береді. Жаңартылатын отын көздеріне көшкенге дейін ол энергия тасымалдаушыларға қажеттілікті қамтамасыз ететін мұнай мен газдың жаңа сапалы қорларын беруге арналған. Олар таусылған кен орындарының орнына келу керек, себебі олардың дамуы жоғары көмірсутекті ізге ие.

Әлемдік тәжірибе көрсеткендей нарықтық ортада юниорлық компанияның жаңа кен орындарын іздеу міндетін сәтті орындауда. Олар ұтқырлықпен және жаңа технологиялар мен білімді кеңінен қолданумен ерекшеленеді.Олардың қызметінің ең жақсы нәтижелері құрылымы күрделі аудандарда байқалады, инновациялар мұнай-газ жинақтаудың жаңа аймақтарын анықтауға мүмкіндік береді. Қазіргі деректер жаңа ашылулардың Ресей мен Қазақстан аумағындағы Орал алдындағы аймағының зор әлеуеті бар екенін көрсетеді. Солтүстік-Орал мұнай-газ компаниясының жұмыс тәжірибесі ол перспективалы құрылымды анықтауға мүмкіндік беретін жаңа жобаның мысалын келтіріп, мұнай мен газдың ірі қорларын қамтуға қабілеттілігін көрсетеді.

ТҮЙІн СӨЗДЕР: геологиялық барлау, ресурстық база, мұнай, газ, сапалық қор, юниорлық компаниялар, инновациялық технологиялар, Орал алды, Чернышев жотасы, тұзды диапирлер.

\section{PETROLEUM EXPLORATION AND JUNIOR COMPANIES: AN EXAMPLE OF AN EXPLORATION PROJECT IN THE SUB-POLAR URALS THRUST BELT}

K.O. SOBORNOV*, Founder of North-Uralian Petroleum Co, Ltd, PhD, https://orcid.org/0000-00029073-8492

NORTH-URALIAN PETROLEUM CO. LTD.,

Russia 142784, Moscow, Kievskoye sh. 1, business park Rumyantsevo

A review of global trends in the petroleum industry suggests the emerging role of oil and gas exploration. It should provide new reserves that will cover demand for oil and gas before renewable sources of energy will replace fossil fuels. The advantaged hydrocarbons should replace depleted ageing fields, development of which has large hydrocarbon footprint. An analysis of international exploration performance indicated that junior exploration companies are very efficient in the market environment. They tend to be flexible and sensitive to new technologies and concepts.

Their performance is the best in geologically complex areas, where innovations provide opportunities to identify new oil-and-gas accumulation areas. Recent geological studies demonstrated high exploration potential in the Uralian Foreland in Russia and Kazakhstan. A case study of the North-Uralian Petroleum company provides an example of a new exploration project, which resulted in the delineation of a large prospect capable of hosting vast oil-and-gas reserves.

KEY WORDS: petroleum exploration, resource base, oil, gas, advantaged hydrocarbons, junior companies, innovation technologies, Uralian Foreland, Chernyshev Swell, thrust belt, salt diapir.

Состояние ресурсной базы, тенденции геологоразведки и юниорные компании

Современная нефтедобыча России и Казахстана в основном обеспечивается запасами месторождений, которые были открыты главным образом в 1960-1980-х гг. 
Это стало следствием сочетания ряда факторов. Главными из них являются: высокий первичный нефтегазоносный потенциал основных осадочных бассейнов страны и мобилизация экономических ресурсов в рамках плановой экономики. В результате последовательных усилий была создана уникальная ресурсная база нефтегазодобычи, ставшая в дальнейшем основой экономического развития новых независимых государств бывшего СССР. Главным приоритетом нефтегазовой отрасли с начала 1990-х гг до настоящего времени является максимизация экономической ценности существующих запасов за счет наращивания добычи. Она обеспечивалась повышением нефтеотдачи на существующих месторождениях за счет массового разведочного бурения и применения новых технологий. Эта стратегия доказала свою эффективность, обеспечив быстрый рост капитализации нефтегазовой отрасли, ставший локомотивом роста экономики.

Обратной стороной успеха добычной отрасли явилось прогрессирующее истощение сырьевой базы. При этом последовательно снижалась роль геологоразведки, которой новая нефтяная экономика отводила второстепенную роль. Во многих компаниях геологоразведка финансировалась по остаточному принципу, в результате чего она стала приобретать ритуальный характер. Это вело к утере ключевых компетенций в области геологии, что вызывало падение эффективности новых поисковых проектов. В перспективе эта тенденция создает серьезные угрозы для развития отрасли. Хотя формальные количественные параметры ресурсной базы нефтедобычи в России выглядят комфортно, обеспечивая не менее 20-30 лет текущей добычи, качество ресурсной базы в последние годы вызывает растущую озабоченность отраслевых экспертов (Соколов, 2021 и др.). Деградация ресурсной базы ведет к снижению производительности нефтедобычи и росту доли нерентабельных запасов, которая в России в настоящее время составляет около 36\% (Выгон, 2019). Средний дебит нефти в России в 2020 г опустился до 7,7 т/с, снижается качество сырья, обводненность добываемой нефти в районах традиционной добычи превышает 90\% (Нефтегазовый..., 2021).

Безусловно, для восполнения ресурсной базы нефтегазодобычи в последние годы делается немало. Ежегодные приросты запасов близки или превышают объемы добытой нефти. Однако большинство новых месторождений являются мелкими или находятся в удаленных районах, освоение которых требует больших затрат и может занять многие годы. В последние 5 лет на новые месторождения России со сроком ввода в эксплуатацию не старше 5 лет приходится в среднем около 36 млн т нефти, что составляет только около 7\% общей добычи (Нефтегазовый..., 2021). Очевидно, что сохранение этой тенденции угрожает стабильному развитию отрасли.

Кроме упомянутых внутренних тенденций развития нефтегазовой отрасли в последние годы появились новые факторы, которые связаны с глобальной трансформацией энергетики. Представляется, что ожидаемые структурные изменения отрасли резко повысят значение геологоразведки. Дело в том, что согласованные международные требования к сокращению выбросов парниковых газов и иных видов воздействия на окружающую среду будут создавать невыгодные условия для поддержания добычи на истощенных месторождениях. Извлечение нефти на таких месторождениях требует повышенных удельных затрат энергии и дорогостоящих 
мероприятий по защите окружающей среды. В скором времени к этому добавиться прогрессивная плата за выбросы $\mathrm{CO}_{2}$. В этой связи следует ожидать роста запроса на новые месторождения, которые, способны давать высокие притоки безводной нефти. Экономика разработки таких месторождений будет иметь существенные преимущества, в том числе и за счет меньшего углеродного следа.

Значительные различия в экологическом качестве истощенных и новых месторождений обусловили появление нового термина - advantaged hydrocarbons (Davies and Simmons, 2021 и др.), которое можно перевести как качественные или продвинутые запасы УВ. Появление этого понятия подчеркивает актуальность замены истощенных залежей свежими более экологичными источниками нефти и газа, которыми должны стать новые высокодебитные месторождения. Запрос на такие открытия, вероятно, будет быстро расти. Согласно современным оценкам, для удовлетворения мирового спроса на углеводороды в дополнение к существующим запасам в ближайшие 30 лет (до полного перехода на возобновляемые источники энергии) потребуется прирастить 38,9-48,9 млрд. т нефти и 620-650 трлн м газа (Davies and Simmons, 2021). Достижение этих целей в обозримом будущем требует существенного наращивания геологоразведочных работ.

В этой связи особую актуальность приобретает вопрос: возможны ли новые крупные высокодебитные открытия в известных бассейнах, которые могут заменить старые залежи? Тот факт, что за последнее время таких открытий в России и Казахстане было немного, как будто дает основание думать, что это маловероятно. Вместе с тем, анализ новых данных, характеризующих строение ряда нефтегазоносных бассейнов, а также мировая практика показывают, что это возможно (Соборнов, 2016, Sternbach, 2020 и др.).

Обобщение опыта поисковых работ показывает, что с наибольшей вероятностью успехи достигаются там, где в них используются новые технологии и знания. Кроме этого, наибольшая результативность достигается при участии геологоразведке большого числа компаний, чем обеспечивается конкуренция и обмен лучшим опытом. Именно этими факторами была предопределена сланцевая революция в США (Fryklund and Stark, 2020 и др.). Небольшие юниорские компании явились инициаторами многих крупнейших проектов, которые привели к крупнейшим новым открытиям в акватории Гайаны, Израиля, Мозамбика и других, которым в последствие были приобретены компаниями-мейджорами. Эти и многие другие примеры показывают, что благодаря высокой мобильности и восприимчивости к инновациям в конкурентной среде небольшие независимые компании и юниоры превосходят по эффективности крупные компании (Kaznacheev and Bazaleva, 2016 и др.). Последним проще приобретать успешные проекты, пользуясь доступом к дешевым кредитам, не принимая на себя риски геологоразведки.

С точки зрения геологии, накопленный опыт показывает, что наилучшие результаты получены в районах сложного геологического строения, таких как складчатые пояса, соленосные бассейны, крупные дельты. Это объясняется тем, что технологии, которые применялись при их изучении в прошлом, часто были неадекватны сложности их строения, что в итоге вело к неудачам. Современные технологии и знания позволяют выявлять в подобных районах новые зоны нефтегазонакопления, 
способные содержать крупные залежи нефти и газа. Исходя из этого, можно сделать вывод о том, что в настоящее время особую актуальность приобретает задача ревизии накопленных данных и выявления регионов, где возможно обнаружение новых типов зон нефтегазонакопления, а также пропущенных залежей за счет использования новых технологий и знаний. Именно в подобных условиях в последние годы были открыты крупные месторождения, такие как, например, Зор и Левиафан и в Восточном Средиземноморье, Лула и Бузиос в Бразилии, Зама в Мексиканском заливе, Кешен в Таримском бассейне Китая и другие.

В России примером может быть Нерцетинское нефтяное месторождение в Северном Предуралье (Тимано-Печорский бассейн). Оно стало крупнейшим нефтяным открытием в России в 2016 г. (Лазеев и др., 2016). Это месторождение было открыто на площади, выведенной из бурения с отрицательным результатом в 1980-х гг. Проведенная нашей группой переинтерпретация данных прошлых лет, показала наличие пропущенных нефтенасыщенных пластов на этой структуре, что подтвердило последующее бурение. Этот пример показывает, что перспективным районом для проведения поисковых работ на новом технологическом уровне может быть Предуралье (рисунок 1). В пользу этого соображения свидетельствует также данные современных исследований, характеризующих строение и нефтегазоносный потенциал этого района с использованием новых данных и геологических концепций.

В настоящее время крупные компании не проявляют большого интереса к Предуралью. Это связано с тем, что этот район традиционно воспринимается как достаточно зрелый, где трудно рассчитывать на крупные открытия. Основной интерес в России для крупных компаний в настоящее время представляют арктические районы, а также Восточная Сибирь и Дальний Восток, ресурсы которых ориентированы на рынок Китая. Эта ситуация создает благоприятную нишу для развития новых проектов юниорными компаниями в Предуралье.

\section{Гряды Чернышева: предпосылки нефтегазоносности}

Региональное исследование Предуралья показало, что одним из наиболее перспективных районов для формирования крупной зоны нефтегазонакопления является область сочленения Косью-Роговской впадины и гряды Чернышева (Соборнов, 2016; Грунис и др. 2016; Данилов, 2017 и др.). В ее пределах крупнейшая впадина Предуралья сочленяется со складчато-надвиговой системой гряды Чернышева. На протяжении значительной части этого структурного тренда аллохтонные пластины гряды Чернышева, в основании которых залегает толща верхнеордовикской соли, перекрывают осадочный чехол краевого прогиба (рисунок 2). Горизонтальная амплитуда надвиговых перекрытий достигает 10 км и более.

Комплексное изучение строение гряды Чернышева с применением сейсморазведки 3Д, электроразведки и других несейсмических методов показало, что формирование надвиговых структур в рассматриваемом районе было связано с продолжительной последовательностью тектонических событий (Соборнов и др., 2021). Она включала следующие основные этапы: (1) длительное формирование соляных валов за счет соли, поступавшей из прилегающей Косью-Роговской впадины, (2) сжатие соляных валов в условиях коллизионной складчатости с образованием выжатых соляных покровов, и (3) формирование крупно-амплитудных надвигов 


\section{ГЕОЛОГИЯ}

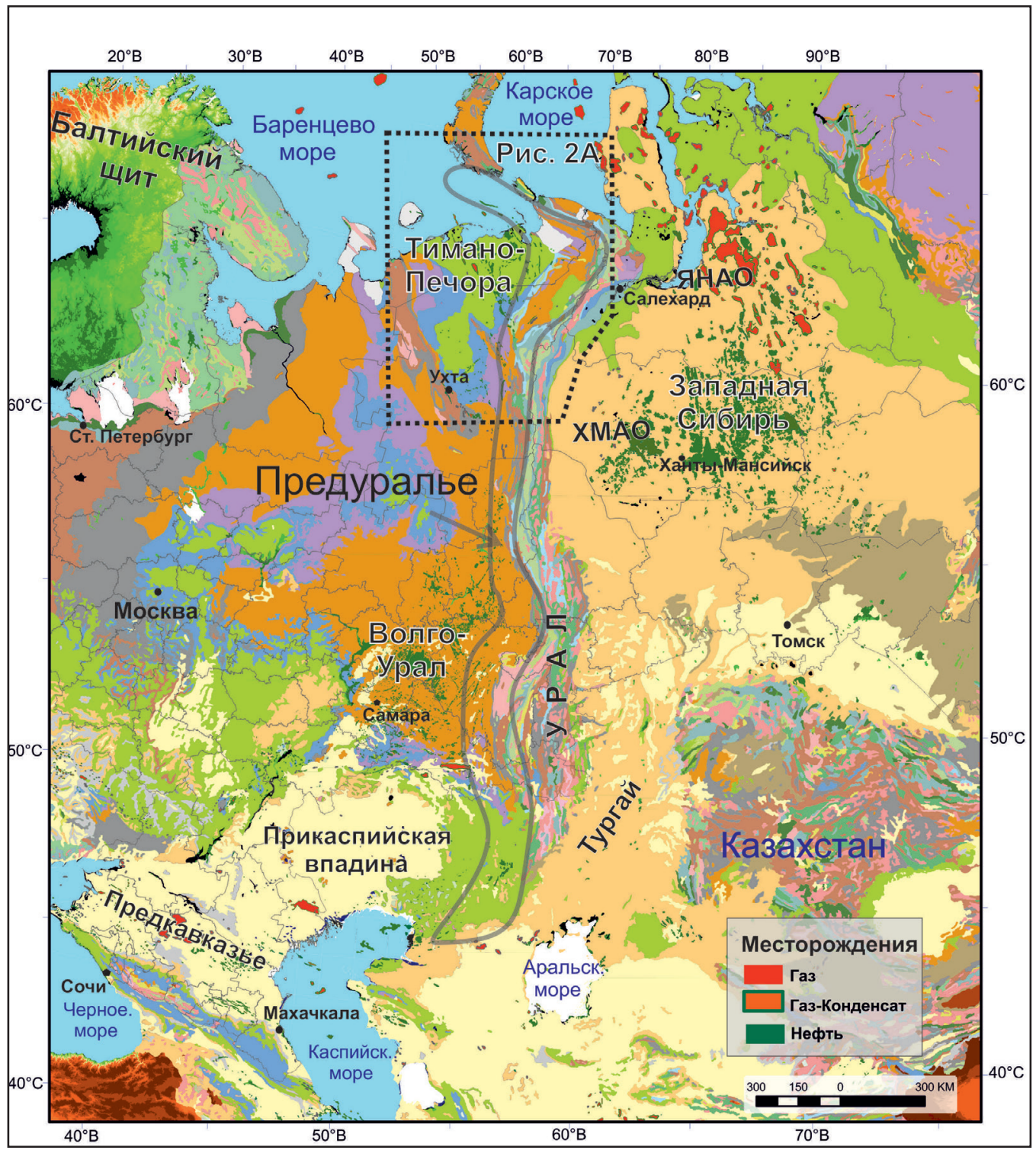

Рисунок 1 - Обзорная схема размещения основных нефтегазоносных бассейнов уральского региона России на основе геологической карты.

Рамкой выделен район, показанный на рисунке 2

за счет расслоения осадочного чехла впадины по верхнеордовикским солям и пододвигание надсолевых отложений под соляные массивы с образованием надвигов, вергентность которых противоположна генеральной (рисунок 3).

Описанная последовательность событий объясняет специфические особенности строения осадочного чехла, которые ранее представлялись загадочными. Так, например, широкое распространение в данной зоне брекчированных силурийско-ордовикских отложений логично объясняется формированием раздавленных соляных 


\section{ГЕОЛОГИЯ}
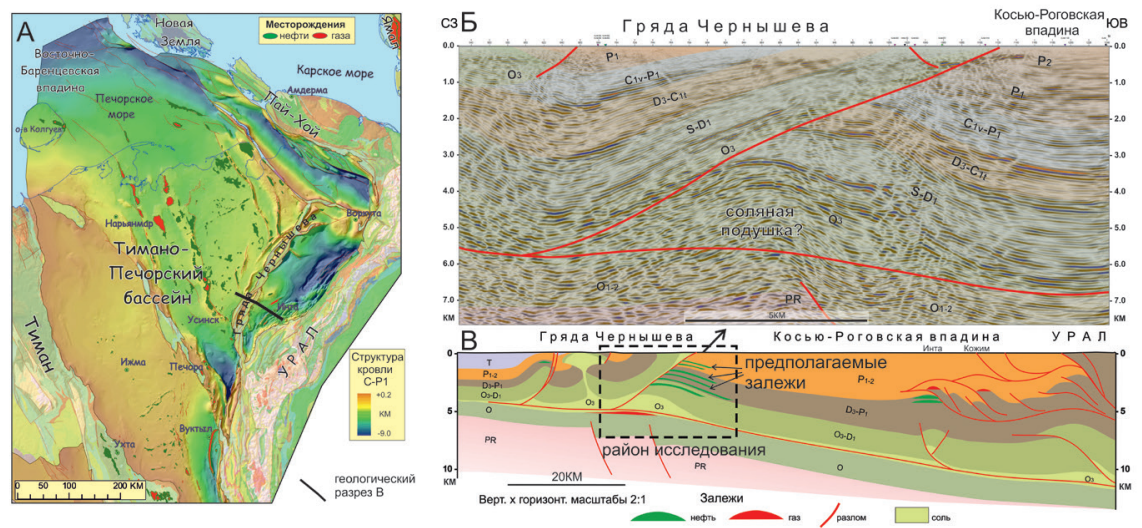

Рисунок 2 - А - Структурная карта Тимано-Печорского бассейна по поверхности нижнепермских карбонатов. Б - интерпретированный сейсмический разрез Поварницкого поднятия в глубинной области. В - региональный геологический разрез южной части Косью-Роговской впадины и прилегающих складчатых зон. Выделено положение района исследования, а также известных и предполагаемых залежей нефти и газа. Положение геологического разреза показано на карте А.

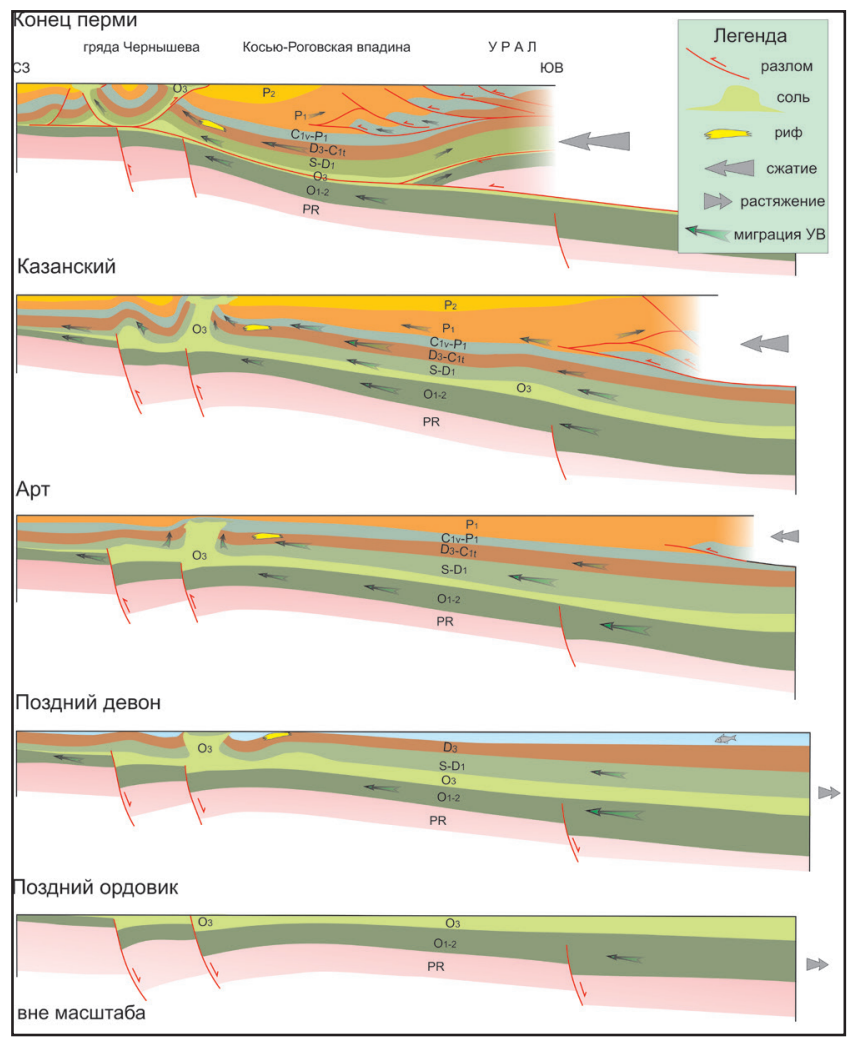

Рисуок 3 - Схема структурного развития южной части Косью-Роговской впадины и гряды Чернышева в ордовике-перми с указаниями направления миграционных потоков УВ (Соборнов и др., 2021 с дополнениями). Акцентирована структурообразующая роль верхнеордовикских эвапоритов 
диапиров с выжиманием соли к поверхности. Этот процесс вел к образованию эвапоритовых брекчий, возникших за счет растворения соли на поверхности, и способствовал фрагментации пород кепроков соляных поднятий. Итогом структурного развития зоны сочленения гряды Чернышева и Косью-Роговской впадины явилось образование протяженной зоны надвиговых перекрытий осадочного чехла КосьюРоговской впадины. Общий региональный подъем чехла в западном направлении, локально усиленный утолщением солей, приводил к тому, что в поднадвиговой зоне располагалась наиболее приподнятая часть осадочного разреза. Эта структурная конфигурация создает зону тектонически ограниченных поднадвиговых поднятий, которыми могут быть связаны тупиковые ловушки углеводородов, мигрировавших из прилегающей Косью-Роговской впадины.

Количество углеводородов поступавших из Косью-Роговской впадины, вероятно, было очень значительным. Эта впадина представляет собой обширную и самую глубокую краевую депрессию Предуралья, толщина палеозойского осадочного чехла которой составляет около 15 км. В составе осадочного выполнения установлено наличие нескольких высокопродуктивных нефтематеринских интервалов, наиболее важным из которых являются доманиковые отложения франского яруса. Согласно оценке ведущих специалистов по геохимии только доманиковые отложения Косью-Роговской впадины произвели около 300 млрд. т. нефти (Баженова и Богословский, 2012).

Строение этой впадины, которая в геологической истории представляла собой бассейн континентальной окраины Уральского океана, позднее преобразованная в краевой прогиб перед фронтом надвигового пояса, создавала условия для длительной массовой миграции нефти по восстанию слоев в направлении гряды Чернышева (рисунок 3). За счет поступления нефти крупных краевых прогибов в направлении прилегающих поднятий были сформированы крупнейшие залежи нефти и битумов мира. К их числу относятся битумные поля Ориноко, Атабаска, Оленек, а также уникальные месторождения как Гхавар (Саудовская Аравия) и Прудо-Бей (Аляска) и многие другие. Таким образом, поднадвиговый тренд на восточной периферии гряды Чернышева находится в исключительно благоприятных условиях для формирования крупной зоны нефтегазонакопления.

\section{Поисковые работы на поднадвиговом тренде}

Выявление благоприятных условий для формирований залежей нефти и газа в зоне сочленения гряды Чернышева и Косью-Роговской впадины стало возможным благодаря получению новых сейсмических данных в начале 1990-х гг. Их интерпретация показала существование поднадвигового продолжения осадочного чехла под тектоническим фронтом гряды Чернышева (Соборнов и Пильник, 1991). В северной части гряды Чернышева для изучения поднадвигового разреза была заложена скважина 1-Воргамусюр. К сожалению, в процессе ее бурения произошел аварийный выброс нефти дебитом до $500 \mathrm{~m}^{3} / \mathrm{c}$, за которым последовал пожар, уничтоживший скважину (Данилов, 2017). Нефть была получена из карбонатных отложений неопределенного возраста, перекрытых солями верхнего ордовика.

Мощное нефтепроявление привлекло большое внимание нефтяных компаний. На последующем аукционе участок, на котором находилась эта скважина, а также 
соседние участки были приобретены на рекордные суммы. Ожидалось, что опоискование подсолевых ловушек на восточном фланге гряды Чернышева даст быстрые открытия. Вскоре по соседству со скважиной 1-Воргамусюр было пробурено еще 3 глубокие скважины с целью опоискования поднадвигового разреза. Точки заложения скважин были определены на основе разряженной сети сейсмических данных 2Д. Скважины полностью подтвердили представления о крупном надвиговом перекрытии осадочного чехла Косью-Роговской впадины надвиговыми пластинами гряды Чернышева, в основании которого залегала соленосная толща мощностью до 1 км. В скважинах были установлены значительными нефтепроявлениям, однако промышленных открытий сделано не было. Наиболее существенные результаты были получены в скважине 2-Адак (рисунок 4). В ней было установлено нефтенасыщение в нижнедевонских карбонатах, перекрытых аллохтонными солями. К сожалению, технические сложности не позволили качественно испытать эту скважину (Данилов, 2017).

Общий негативный результат проведенных работ вызвал глубокое разочарование, дальнейшие работы были остановлены, а большинство лицензий было сдано. Крупные компании потеряли интерес к этому району, сочтя его высокорискованным. Эта ситуация создала возможности для реализации поисковых проектов юниорными компаниями, к числу которых относится Северо-Уральская нефтегазовая компания (СУНГК).

Исследования, выполненные специалистами СУНГК, показали, что в районе пробурённых скважин в поднадвиге отсутствовала замкнутая ловушка. Независимо этот вывод был сделан также другими исследовательскими группами (Грунис и др., 2016 и др.). Было также установлено, что приток нефти в скважине 1-Воргамусюр был получен из карбонатной глыбы, заключенной в толще аллохтонных солей (Данилов, 2017). Эти сведения показали, что размещение ранее пробуренных скважин

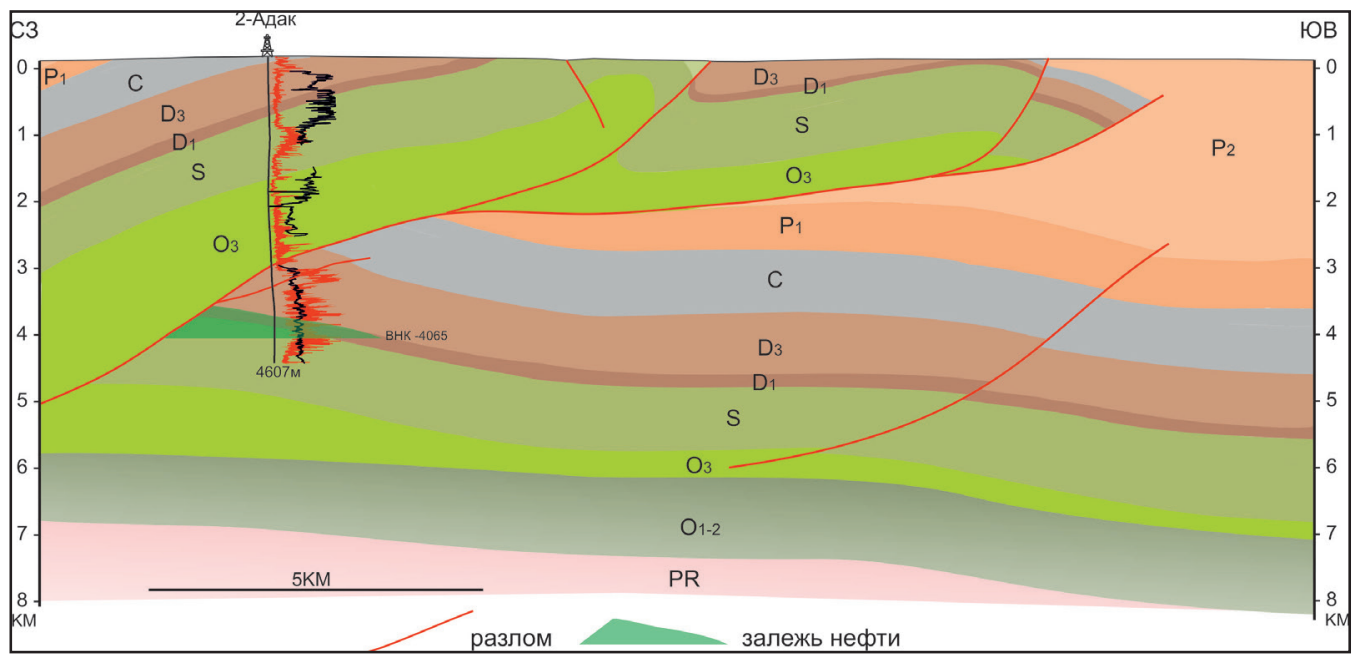

Рисунок 4 - Геологический разрез зоны сочленения гряды Чернышева и Косью Роговской впадины в районе скважины 2-Адак (по Данилову, 2017 с упрощениями и дополнениями). Показана залежь нефти в нижнедевонских отложениях. Каротажные диаграммы: ГК- красная, ПС- черная. Положение разреза см. на рисунке 6 


\section{ГЕОЛОГИЯ}

было сделано на основе неполной и не точной информации. Оценивая результаты работ на поднадвиговый тренд, следует заметить, что многие крупные месторождения в надвиговых поясах были открыты после бурения значительно числа сухих скважин (Duval, 2015 и др.).

Проведенный анализ позволяет сделать вывод о том, что проведению поискового бурения в зонах сложного строения должны предшествовать региональные исследования, которые позволят уточнить структурой план и наметить наиболее надежные ловушки в контексте формирования нефтегазовых систем. Район заложения скважин должен быть исследован с применением сейсморазведки 3 Д и несейсмических методов, что позволит получить детальную информацию о целевых объектах и определить вероятные технические риски проводки скважины. В условиях сложных деформаций солей целесообразно дополнение сейсморазведки электроразведкой МТЗ, данные которой способны закрыть «немые» сейсмические участки и существенно уточнить интерпретация в поднадвиговых зонах (Соборнов и др., 2021).

\section{Строение Поварницкой ловушки}

Исходя из уроков прошлого, для оценки нефтегазоносного потенциала зоны сочленения гряды Чернышева и Косью-Роговской впадины нашей компанией было выполнено региональное исследование, которое позволило определить приоритетное направление поисковых работ на поднадвиговый тренд. Эта работа позволила сделать вывод о том, что наибольший поисковый интерес в его пределах представляет район Поварницкого поднятия, которое является крупнейшей положительной структурой Косью-Роговской впадины (рисунок 2).

В 1980-х годах на этом поднятии были пробурены 3 глубокие скважины, в одной из них при испытании в колонне был получен приток легкой нефти из верхнедевонских отложений дебитом 4,9 м³/с. В остальных были отмечены нефтепроявления. По результатам работ был сделан вывод о том, что открыта мелкая залежь нефти, которая не представляла экономической ценности. Новая интерпретация геолого-геофизических данных, с использованием материалов сейсморазведки, полученных в последующие годы, показала, что пробуренные скважины были размещены неудачно. Поварницкое поднятие продолжается к западу, где его перекрывает аллохтонная пластина гряды Чернышева. Согласно современной интерпретации скважины были заложены на далеком склоне поднятия, вершина которого заключена в поднадвиговой зоне. Это позволило предполагать наличие в этом районе крупной перспективной структуры.

Структурное картирование Поварницкого поднятия и прилегающих районов показало, что это поднятие имеет критически важные латеральные замыкания. Основной риск для существования ловушки был связан с наличием надежной соляной покрышки со стороны гряды Чернышева. Для оценки вероятности наличия такой покрышки СУНГК в 2018-2019-гг были проведены дополнительные сейсмические исследования 3Д в комплексе с магнитотеллурическим зондирование, грави- и магниторазведкой. Были также переобработаны данные сейсморазведки прошлых лет. Интерпретация полученных результатов показала, что соленосная толща в основании аллохтонной пластины гряды Чернышева в районе исследования присутствует, ее 
толщина составляет до 1 км (Соборнов и др., 2021). Этот вывод существенно повысил оценку нефтегазоносного потенциала Поварницкого поднятия.

Сравнение представлений о строении Поварницкой ловушки 1980-х гг. и современная интерпретация показаны на рисунке 5. Как можно видеть, низкая разрешающая способность данных сейсморазведки 1980-х гг. делала невозможным выявление поднадвиговой части этого поднятия. Современные геофизические данные значительно расширяют контуры ловушки, а также существенно уточняют ее строение. Картирование Поварницкой ловушки показывает, что на уровне поверхности визейского несогласия площадь этой ловушки составляет не менее 250 км² $^{2}$ рисунок б). Глубины залегания перспективных горизонтов в вершинной части поднятия примерно на 1 км выше, чем в ранее пробуренных скважинах. На основании этих данных были намечены новые поисковые объекты.

С глубиной площадь структуры увеличивается, а ее вершина смещается к западу, что связано с наклонным положением перекрывающего надвига. Интерпретация данных каротажа скважин, пробуренных в этом районе, указывает на высокую вероятность существование в пределах Поварницкого поднятия многозалежного месторождения. Основные коллекторские горизонты ожидаются в регионально нефтегазоносных силурийско-нижнепермских отложениях, залегающих на глубинах от 1 до 4 км. Большая высота ловушки дает основание рассчитывать на высокую пластовую энергию залежей, что может обеспечить крупные дебиты нефти и газа. Локально коллекторские свойства резервуаров могут быть улучшены за счет карстования карбонатных отложений. Признаки карста выделяются по сейсмическим

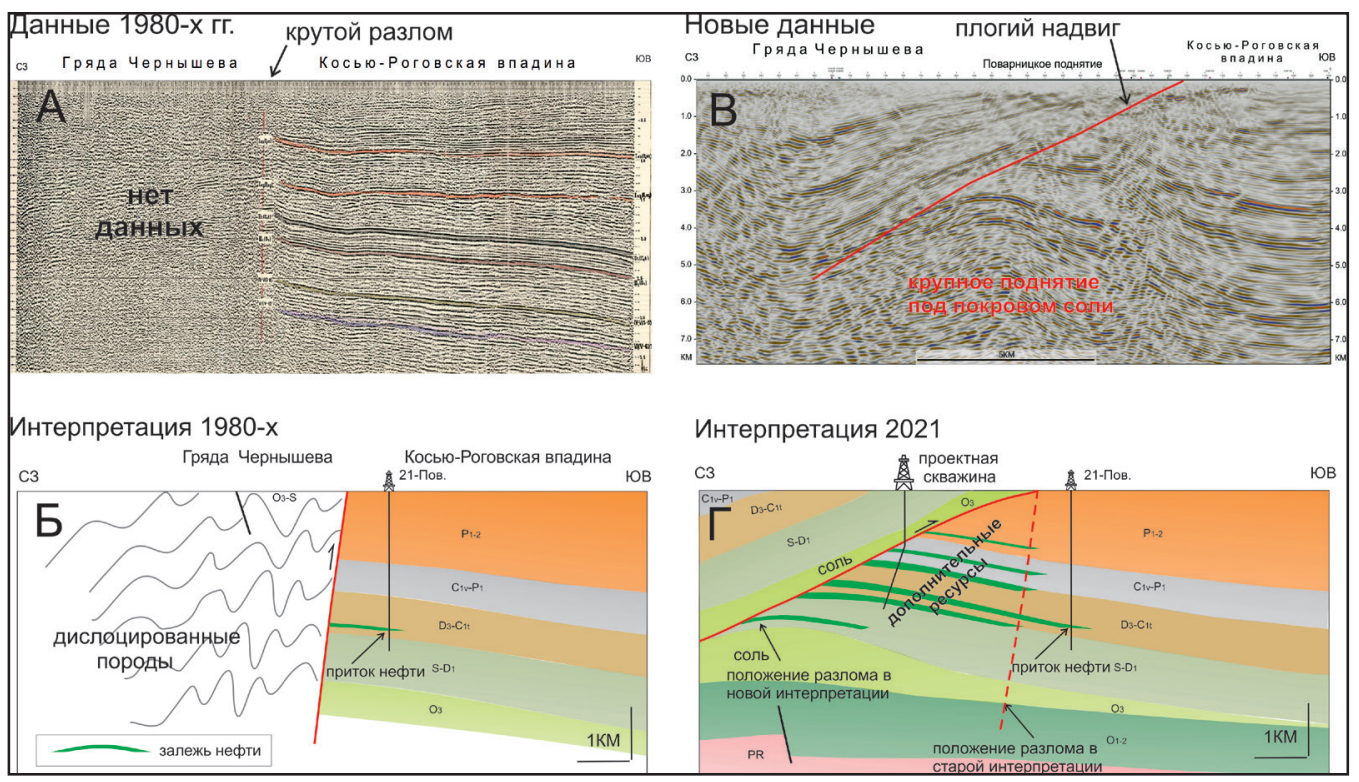

Рисунок 5 - Сейсмический профиль (А) и геологическая интерпретация строения (Б) зоны сочленения гряды Чернышева и Косью-Роговской впадины в районе Поварницкого поднятия

1980-х гг. Новый сейсмический профиль (В) и современная геологическая интерпретация строения (Г) этого района. Схематически показано распределение известной залежи нефти (скв. 21-Поварницкая), а также предполагаемых залежей нефти и газа. 


\section{ГЕОЛОГИЯ}

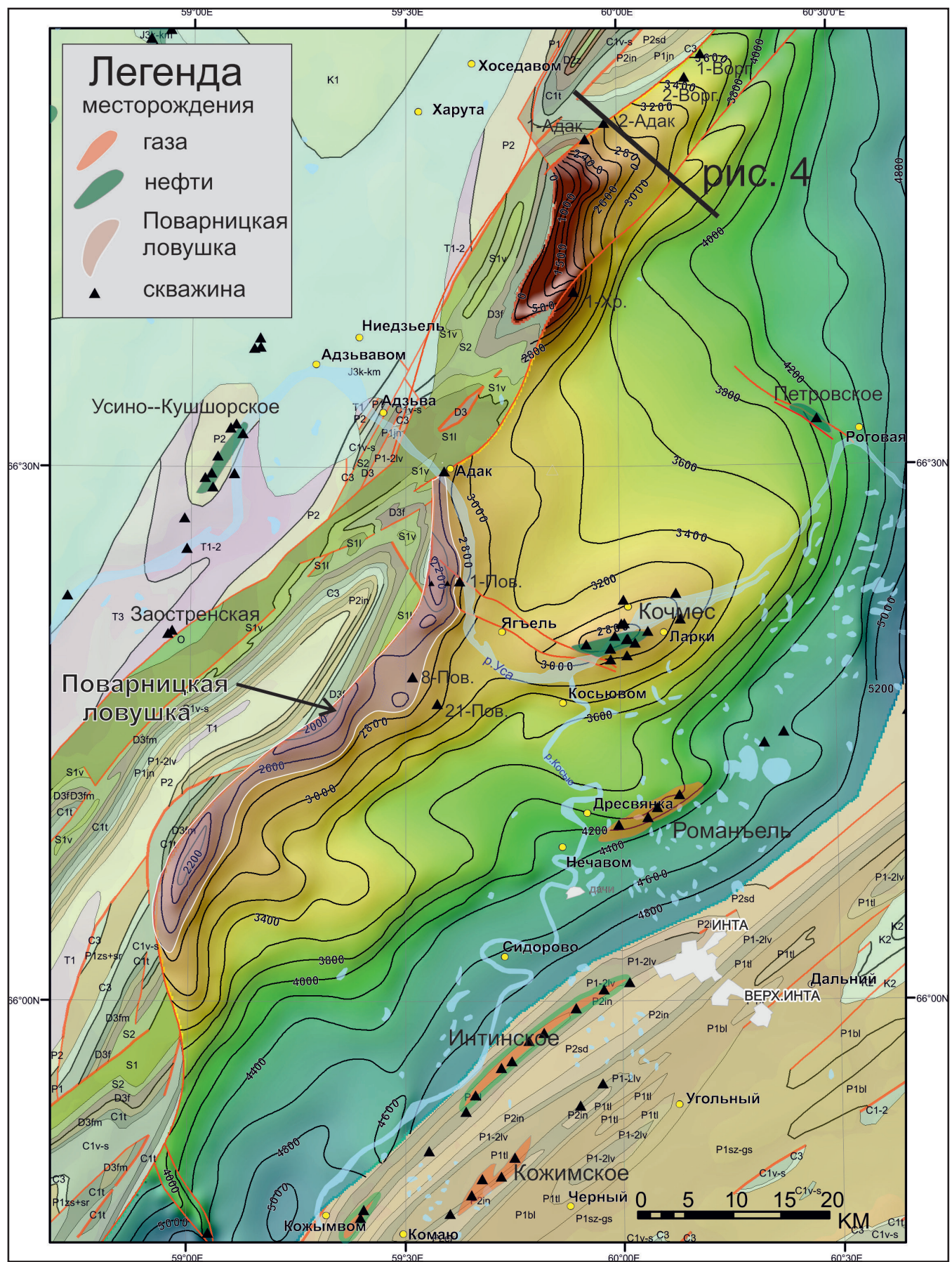

Рисунок 6 - Схематическая карта по поверхности визейского несогласия с удалением аллохтонного комплекса гряды Чернышева, составленная на основе переинтерпретации данных сейсморазведки 2Д и ЗД (Соборнов и др., 2021 с дополнениями).

Выделена Поварницкая ловушка 
данным. В настоящее время ведется проектирование новой поисковой скважины, цель которой состоит в опоисковании сводовой части Поварницкого поднятия в поднадвиговой зоне. Ресурсный потенциал этого района дает основание рассчитывать на создание нового центра нефтедобычи.

\section{Заключение}

Современное состояние ресурсной базы нефтедобычи в России и Казахстане, а также мировые тенденции в области трансформации энергетики, указывают на важность прироста новых запасов. Потребность в них в ближайшие годы будет высока. Они должны заменить старые истощенные месторождения, разработка которых является низкорентабельной, а также имеет возрастающие негативные экологические последствия.

Анализ мировых тенденций в геологоразведке показывает, что основной прирост запасов нефти и газа следует ожидать в районах сложного геологического строения, где передовые технологии и знания могут способствовать выявлению новых зон нефтегазонакопления. К числу таких районов относится Предуралье, характеризующееся большим разнообразием структурных стилей деформаций и высокой изменчивостью литолого-стратиграфического состава осадочного чехла. В прошлом, информативность использовавшихся методов не соответствовала сложности геологических условий, что снижало результативность поисковых работ. В настоящее время Предуралье представляет собой благоприятную нишу для развития новых проектов юниорными компаниями. Одним из них является геологоразведочный проект в районе Поварницкого поднятия, осуществляемый Северо-Уральской нефтегазовой компаний. Опыт этой компании показывает возможность выявления новых крупных поисковых объектов там, где они были пропущены в прошлом. Вероятно, данная ситуация не уникальна и новые крупные поисковые объекты могут быть выявлены в других районах Предуралья в России и Казахстане.

\section{ЛИТЕРАТУРА}

1 Баженова Т.К., Богословский С.А. Результаты расчетного моделирования нефте- и газообразования в прогибах Тимано-Печорского бассейна. Доклад на научно-практической конференции «Комплексное изучение и освоение сырьевой базы нефти и газа севера европейской части России», Санкт-Петербург, ВНИГРИ. - 2012, CD-ROM. [Bazhenova T.K. and Bogoslovskiy C.A. Resultes of numerical modeling of oil and gas generation in foredeeps of the Timan-Pechora Basin. Conference paper at scientificindustrian coinference "Integrated exploration and development of reserve base of oil and gas production of the Northern part of European Russia", St. Petersburg, VNIGRI, 2012, CD-ROM].

2 Грунис Е.Б., Ростовщиков В.Б., Богданов Б.П. Соли ордовика и их роль в особенностях строения и нефртегазоносности северо-востока Тимано-Печорской провинции // Георесурсы. - 2016. - № 18, 1. - C. 13-23. [Grunis, E.B., V.B. Rostovshchikov, and B.P. Bogdanov, The Ordovician salt and their role in structural peculiarities and petroleum habitat of the northeastern Timan-Pechora Province // Georesources. - 2016. - № 18,1. - Р. 13-23].

3 Данилов В.Н. Гряда Чернышева: геологическое строение и нефтегазоносность. СПб., Реноме, 2017. - 288 с. [Danilov V.N. The Chernyshev ridge: geological structure and petroleum potential. St.Petersburg: Renome; 2017. 288 p. (in Russian).] 
4 Выгон Г., Инвентаризация запасов: от государственной экспертизы к национальному аудиту. // Нефтегазовая вертикаль - 2019. - 18. - С. 19-24. [Vygon G. Inventory of reserves: from the state expertise to the national audit // Oil and gas vertical. - 2019. 18. - P. 19-24 (in Russian)]

5 Лазеев А.Н., Гайдук А.В., Гнутова Э.Н., Никитин Ю.И., Попов В.Г., Стрельников Т.М., Фищенко А.Н., Хайруллина Е.А. Геолого-разведочные работы ПАО «НК «Роснефть». Результаты, достижения, планы // Геология нефти и газа. - 2016. - N 5. - P. 75-84. [Lazeev A.N., Gaiduk A.V., Gnutova E.N., Nikitin lu.I., Popov V.G., Streltsov T.M., Fitschenko A.N., Khairullina E.A. JSC "NK "Rosneft" geological exploration. Results, accomplishments, plans. Geologiya nefti i gaza. 2016;(5):75-84,(in Russian)]

6 Филимонова И.В., Немов В.Ю., Проворная И.В. и др. Нефтегазовый комплекс России. Ин-т нефтегазовой геологии и геофизики им. А.А. Трофимука СО РАН. - Новосибирск: ИНГГ СО РАН, 2021. Часть 1. Нефтяная промышленность - 2020: долгосрочные тенденции и современное состояние. - 88 c. [Oil and gas complex of Russia. /I.V. Filimonova, V.Yu. Nemov, I.V. Provornaya et al., Institute of geology and geophysics named after A.A, Trofimuk, Siberian Branch of Russian Acad. of Sci., 2021. Part 1, Oil industry- 2020: long-termed tendencies and present situation. - 88 р., (in Russian).]

7 Соборнов К.О., Пильник Л.В. Гряда Чернышева - фронт вдвиговой пластины? // Доклады. АН CCCP. - 1991. - Т. 318. - С. 430-433. [Sobornov, K.O. and L.F. Pil'nik, 1991, Is the Chernyshev Swell a front of the wedge-shaped thrust? // Doklady AN USSR (Reports of the USSR Academy of Sciences). - 1991. - T. 318. - P. 430-433, (In Russian)]

8 Соборнов К.О. Перспективные направления поисков нефти и газа в России в контексте мировых трендов в геологоразведке // Нефтегазовая геология. Теория и практика. - 2016. - N 11. [Sobornov, K.O. Prospective directions of oil and gas exploration in Russiain the context of the World's trends // Geology of oil and gas// Theory and practice. - 2016, 11, 1,(in Russian)].

9 Соборнов К.О., Коротков И.П., Яковлев Д.В., Куликов В.А., Кудрявцев К.Ю., Колесник В.Ф. Раздавленные соляные диапирыгряды Чернышева (Тимано-Печорский бассейн): комплексное изучение и влияние на нефтегазоносный потенциал // Геология нефти и газа. - 2021. - N 1. - C. 73-88. [Sobornov, K.O., Korotkov, I.P., Yakovlev, D.V., Kulikov, V.A., Kudriavtsev, K.Yu. andKolesnik, V.F. 2021. Squeezed diapirs of the Chernyshev Swell, the Timan-Pechora Basin: integrated study and petroleum habitat// Geology of Oil and Gas, 1, 73-88, (in Russian)].

10 Соколов А.. Нефти много, но скоро ее будет не хватать // Нефтегазовая вертикаль. - 2021. - N. 6. - C. 12-16. [Sokolov A., Oil is abundant, but soon it will be in deficit // Oil and gas vertical. - 2021. - N 6. - P. 12-16, (in Russian).]

11 Duval B. 2015. Once Upon a Time... In the Colombian Foothills: Discovery of the Cusiana and Cupiagua Fields. Search and Discovery Article \#20309.

12 Fryklund B. and Stark P. Super basins - new paradigm for oil and gas supply // AAPG Bulletin. - 2020. - T. 104. - N 12. Pp. 2507-2519.

13 Kaznacheev P. and Bazaleva R. A comparison of the roles of privately and state-owned oil companies in developing the Arctic shelf. Energy exploration \& exploitation. - 2016. - N 34 (1). - P. 99-112.

14 Davies A., Simmons M.D.. Demand for 'advantaged' hydrocarbons during the 21st century energy transition // Energy Reports. - 2021. - N. 7. - P. 4483-4497.

15 Sternbach, C.A. Super basin thinking: Methods to explore and revitalize the world's greatest petroleum basins // AAPG Bulletin. - 2020. - T. 104. - N. 12. - P. 2463-2506. 